\title{
KUALITAS FISIK, SENSORIS DAN KADAR KOLESTEROL NUGGET AMPELA DENGAN IMBANGAN FILLER TEPUNG MOCAF YANG BERBEDA
}

\section{PHYSICAL, SENSORY QUALITIES, AND CHOLESTEROL CONTENT OF GIZZARD NUGGET WITH MOCAF FLOUR IN DIFFERENT RATIO}

\author{
Arum Intan Kusumanegara, Jamhari, dan Yuny Erwanto* \\ Fakultas Peternakan, Universitas Gadjah Mada, Jl. Fauna No. 3, Bulaksumur, Yogyakarta, 55281
}

\section{INTISARI}

Penelitian bertujuan untuk mengetahui pengaruh perbedaan proporsi filler tepung mocaf (Modified Cassava Flour) terhadap kualitas fisik, sensoris dan kadar kolesterol nugget ampela ayam. Penelitian dilakukan dengan menggunakan 5 level filler tepung mocaf dan ampela dengan imbangan $0: 100 ; 5: 95 ; 10: 90 ; 15: 85 ;$ dan $20: 80$. Data yang diambil adalah kualitas fisik ( $\mathrm{pH}$, keempukan, daya ikat air), kualitas sensoris (warna, rasa, tekstur, daya terima) dan kadar kolesterol. Data kualitas fisik dan kadar kolesterol dianalisis dengan analisis variansi Rancangan Acak Lengkap pola searah atau One Way Anova dan data kualitas sensoris dianalisis dengan analisis non-parametrik dengan uji Hedonik Kruskal Wallis. Perbedaan rerata diuji dengan uji Duncan's New Multiple Range Test. Hasil penelitian menunjukkan bahwa perbedaan level filler tepung mocaf berpengaruh pada penurunan keempukan dan peningkatan daya ikat air tetapi tidak mempengaruhi nilai pH. Peningkatan level filler tepung mocaf meningkatkan skor tekstur tetapi tidak mempengaruhi warna, rasa dan daya terima. Peningkatan level filler tepung mocaf tidak berpengaruh terhadap penurunan kadar kolesterol nugget ampela. Kesimpulan dari penelitian adalah bahwa makin tinggi level filler tepung mocaf yang ditambahkan pada nugget ampela akan meningkatkan daya ikat air dan tekstur serta menurunkan keempukan, tetapi tidak merubah daya terima dan kadar kolesterol dari nugget ampela.

(Kata kunci: Nugget ampela, Filler, Tepung mocaf, Kualitas fisik, Kualitas sensoris, Kadar kolesterol)

\section{ABSTRACT}

This experiment was conducted to investigate the effect of different levels of mocaf (Modified Cassava Flour) on physical, sensory qualities and cholesterol content of gizzard nuggets. There were five levels of mocaf and gizzard ratio, namely $0: 100 ; 5: 95 ; 10: 90 ; 15: 85$ and $20: 80$. The data measured were physical qualities $(\mathrm{pH}$, water-holding capacity, and tenderness), sensories (color, flavor, texture and acceptability) and cholesterol content. The data of physical qualities and cholesterol content were analyzed statistically by analysis of variance of one-way classification and the data of sensory qualities were analyzed statistically by non-parametric analysis using Hedonic Kruskal Wallis test. Duncan's New Multiple Range Test was used to determine the significant differences among means. The results showed that different levels of mocaf significantly affected the tenderness and water-holding capacity, but not on the pH. The increasing of filler level increased texture score but not on color, flavor, and acceptability scores. The increasing of filler levels of mocaf did not decrease cholesterol content. It could be concluded that increasing of filler levels of mocaf increase water-holding capacity and texture, and decrease tenderness, but it did not change the acceptability and cholesterol content of gizzard nuggets.

(Key words: Gizzard nuggets, Filler, Mocaf flour, Physical qualities, Sensory qualities, Cholesterol content)

\section{Pendahuluan}

Nugget adalah produk olahan daging yang banyak dikonsumsi dan sangat populer di kalangan masyarakat. Nugget yang dijumpai di pasaran dibuat dari daging ayam, sedangkan nugget yang berbahan dasar ampela yang merupakan by-product dari proses pemotongan ayam belum dikembangkan. Ampela tergolong dalam edible by-product

\footnotetext{
* Korespondensi (corresponding author):

Telp. +62 274 513363, E-mail: yunyer@mail.ugm.ac.id
}

sehingga layak untuk dimakan serta tidak menimbulkan gangguan kesehatan bagi yang memakannya.

Ampela ayam memiliki kandungan protein sebesar 19,04\%, lemak sebesar 10,56\% dan kadar air sebesar 55,89\% (Suhardjo, 1995). Ampela ayam memiliki kadar kolesterol cukup tinggi yaitu 205 miligram per $100 \mathrm{~g}$ (Stephanie, 2008). Variasi pengolahan ampela masih terbilang sedikit, sehingga perlu adanya diversifikasi produk.

Pengolahan nugget komersial yang beredar di masyarakat menggunakan filler (bahan pengisi) 
berupa tepung terigu atau tepung tapioka ataupun tepung lain yang mengandung karbohidrat. Pengolahan ampela ayam menjadi nugget menggunakan filler berupa tepung mocaf menarik untuk diteliti. Mocaf merupakan singkatan dari Modified cassava flour yang berarti tepung singkong yang dimodifikasi. Penggunaan tepung mocaf dilakukan guna menggantikan penggunaan tepung terigu dikarenakan sifat-sifat fisik dari tepung mocaf yang mendekati tepung terigu sehingga mocaf memiliki potensi sebagai bahan pengisi pada nugget ampela. Tepung mocaf merupakan salah satu alternatif pangan lokal yang dapat digunakan sebagai filler karena memiliki kandungan pati yang cukup tinggi yaitu berkisar 85 sampai 87\% (Ariyani, 2010). Fitriadenti (2011) menyatakan bahwa sebanyak 80 persen tepung mocaf dapat mensubstitusi tepung terigu sebagai filler dalam pembuatan nugget. Berbagai penelitian menggunakan tepung mocaf telah berhasil menggantikan tepung terigu, maka tidaklah salah bila tepung mocaf digunakan sebagai filler pada nugget.

Penelitian bertujuan untuk mengetahui pengaruh perbedaan proporsi daging (ampela) dan filler tepung mocaf (Modified cassava flour) terhadap kualitas fisik, sensoris (warna, rasa, tekstur dan daya terima) dan kadar kolesterol nugget ampela ayam.

\section{Metode Penelitian}

Materi penelitian yang digunakan adalah nugget. Bahan-bahan yang digunakan dalam pembuatan nugget ampela antara lain ampela ayam dan filler tepung mocaf (level filler 0, 5, 10, 15, dan $20 \%$ ), bumbu-bumbu dan air. Bumbu-bumbu yang digunakan adalah garam $(1,5 \%)$, bubuk bawang putih $(1,5 \%)$, pala bubuk $(0,25 \%)$, bubuk lada putih (1\%) dan es batu $11,75 \%$. Bahan lain yang digunakan adalah tepung roti, putih telur, minyak goreng, tisu, aluminium foil, dan air es.
Ampela disiapkan untuk dibersihkan dari lemak, kemudian dicincang untuk digiling. Ampela giling dan tepung mocaf ditimbang sesuai level imbangan filler. Bumbu-bumbu yang terdiri atas putih telur, garam, bawang putih bubuk, dan lada putih ditimbang kemudian dicampurkan pada adonan ampela. Adonan ditambah air es dan diaduk hingga tercampur merata. Adonan dimasukkan dalam loyang dengan ketebalan $1 \mathrm{~cm}$ dan dikukus selama 30 menit. Setelah itu dianginkan dan dipotong dengan ukuran $3 \times 5 \mathrm{~cm}$, kemudian potonganpotongan tersebut digulirkan pada putih telur dan dilapisi tepung roti dan selanjutnya nugget digoreng. Nugget digoreng pada minyak bersuhu $180^{\circ} \mathrm{C}$ selama 3 menit atau hingga warna berubah menjadi kecoklatan, ditiriskan, lalu dibungkus dengan aluminium foil agar tetap hangat. Kemudian nugget diuji kualitas fisik dan sensoris.

Pengujian sifat fisik nugget meliputi derajat keasaman (pH) (Bouton et al., 1971), daya ikat air (\%) dengan metode Hamm (Soeparno, 1998) dan keempukan $(\mathrm{mm})$ yang diukur dengan alat penetrometer (Kartika et al., 1988) dengan berat sampel pengujian keempukan sebesar $50 \mathrm{~g}$. Nilai $\mathrm{pH}$ nugget diukur dengan $\mathrm{pH}$ meter yang telah dikalibrasi dengan buffer $\mathrm{pH}$ 7,0 (Bouton et al., 1971). Analisis kadar kolesterol menggunakan metode LiebermannBurchards (Plummer, 1987) dengan membandingkan absorbansi larutan kolesterol sampel dengan larutan kolesterol standar. Analisis kualitas sensoris dilakukan dengan menggunakan panelis yang tidak terlatih sebanyak 15 orang dengan skor penilaian menurut Astuti (2005), seperti tersaji pada Tabel 1.

Data hasil uji karakteristik fisik dan uji kadar kolesterol dianalisis dengan analisis variansi Rancangan Acak Lengkap pola searah atau One Way Anova. Perbedaan rerata diuji dengan uji Duncan's New Multiple Range Test (Steel dan Torrie, 1993). Data uji sensoris dianalisis dengan analisis non-parametrik melalui uji Hedonik Kruskal-Wallis (Saleh, 1996).

Tabel 1. Skor warna, rasa, tekstur, dan daya terima pada uji sensoris (color, flavor, texture and acceptability score on sensories qualities)

\begin{tabular}{|c|c|c|c|c|}
\hline $\begin{array}{l}\text { Skor } \\
\text { (score) }\end{array}$ & Warna (color) & Rasa (flavor) & Tekstur (texture) & Daya terima (acceptibility) \\
\hline 1 & Kuning (yellow) & $\begin{array}{l}\text { Sangat tidak enak (very } \\
\text { tasteless) }\end{array}$ & $\begin{array}{l}\text { Sangat kasar (very } \\
\text { rough) }\end{array}$ & $\begin{array}{l}\text { Sangat tidak suka (really } \\
\text { don't like) }\end{array}$ \\
\hline 2 & Kuning tua (dark yellow) & Tidak enak (tasteless) & Kasar (rough) & Tidak suka (dislike) \\
\hline 3 & $\begin{array}{l}\text { Coklat muda (light } \\
\text { brown) }\end{array}$ & Agak enak (ratherwell) & Agak halus (ratherwell) & Agak suka (well) \\
\hline 4 & $\begin{array}{l}\text { Coklat keemasan } \\
\text { (golden brown) }\end{array}$ & Enak (delicious) & Halus (smooth) & Suka (like) \\
\hline 5 & Coklat tua (dark brown) & $\begin{array}{l}\text { Sangat enak (very } \\
\text { delicious) }\end{array}$ & $\begin{array}{l}\text { Sangat halus (very } \\
\text { smooth) }\end{array}$ & Sangat suka (really like) \\
\hline
\end{tabular}

Sumber: Astuti (2005). 


\section{Hasil dan Pembahasan}

\section{Kualitas fisik nugget ampela}

Hasil pengujian kualitas fisik nugget ampela dengan menggunakan imbangan filler tepung mocaf yang berbeda disajikan pada Tabel 2 .

Nilai pH. Hasil penelitian menunjukkan bahwa perbedaan proporsi tepung mocaf sebagai filler pada level yang berbeda tidak berpengaruh secara nyata terhadap $\mathrm{pH}$ nugget ampela. Nilai $\mathrm{pH}$ pada nugget ampela dipengaruhi oleh bahan utama yang digunakan yaitu ampela ayam dan bahanbahan lain yang ditambahkan. Hasil pengujian terhadap $\mathrm{pH}$ ampela sebesar 6,41 dan nilai $\mathrm{pH}$ tepung mocaf sebesar 6,83. Nilai $\mathrm{pH}$ komponenkomponen penyusun suatu produk diduga mempunyai hubungan yang erat dengan $\mathrm{pH}$ akhir produk. Nilai $\mathrm{pH}$ ampela yang hampir setara dengan nilai $\mathrm{pH}$ tepung mocaf membuat nilai $\mathrm{pH}$ nugget ampela tidak terpengaruh dengan peningkatan level filler tepung mocaf hingga 20\% (Tabel 2). Komponen utama penyusun nugget adalah ampela dan tepung mocaf sehingga adanya pencampuran adonan hingga homogen dalam pengolahan nugget ampela diduga tidak mempengaruhi nilai $\mathrm{pH}$ produk antar perlakuan. Hasil ini diduga karena interaksi antara daging, filler dan air sebagai komponen mayoritas dengan bumbu-bumbu sebagai komponen minoritas penyusun nugget memiliki nilai $\mathrm{pH}$ yang hampir sama.

Astuti (2005) melaporkan bahwa nilai $\mathrm{pH}$ nugget dengan penggunaan filler tepung terigu adalah 5,42 sedangkan Fitriadenti (2011) melaporkan bahwa penggunaan filler tepung terigu yang disubstitusi dengan tepung mocaf hingga level $80 \%$ tidak berpengaruh secara nyata terhadap nilai $\mathrm{pH}$. Nilai $\mathrm{pH}$ nugget dengan filler tepung mocaf pada penelitian ini lebih tinggi dibandingkan nilai $\mathrm{pH}$ nugget dengan tepung terigu dikarenakan tepung mocaf dihasilkan dari proses fermentasi sehingga menyebabkan nilai $\mathrm{pH}$ dari tepung mocaf lebih tinggi daripada tepung terigu dan mempengaruhi nilai $\mathrm{pH}$ akhir yaitu pada produk nugget.
Daya ikat air. Hasil analisis statistik menunjukkan bahwa nugget ampela dengan level imbangan filler tepung mocaf yang berbeda memberikan perbedaan yang sangat nyata $(P<0,01)$ terhadap nilai daya ikat air. Nilai rerata tersebut menunjukkan adanya peningkatan seiring meningkatnya level imbangan tepung mocaf dalam pembuatan nugget (Tabel 2). Peningkatan daya ikat air disebabkan oleh protein yang saling berinteraksi dan mengakibatkan ruang antar filamen menjadi lebih besar, sehingga air dapat ditahan dan daya ikat air semakin meningkat (Sriwahyuni et al., 2007). Hal ini disebabkan karena semakin banyak tepung yang ditambahkan akan menurunkan kandungan protein dalam adonan sehingga daya ikat air oleh protein daging akan menurun. Meningkatnya imbangan tepung mocaf menyebabkan kandungan protein dalam adonan menurun sedangkan kandungan air dalam adonan meningkat. Tingginya kandungan air dalam adonan mengakibatkan protein yang larut dalam air sedikit sehingga daya ikat air oleh protein daging akan menurun (Hendronoto et al., 2009). Selain itu, proses pemasakan akan menyebabkan perubahan daya ikat air. Hal ini sesuai dengan pernyataan Soeparno (1998) bahwa proses pemanasan akan menyebabkan terjadinya denaturasi protein dan menurunkan daya ikat air. Pemasakan menyebabkan perubahan daya ikat air karena adanya solubilitas protein daging.

Daya ikat air selain dipengaruhi oleh protein ampela sebagai bahan utama juga dipengaruhi oleh tepung mocaf sebagai filler. Salah satu fungsi filler adalah menyerap air dalam produk karena filler mengandung pati yang memiliki gugus hidroksil. Pati pada tepung mocaf memiliki kemampuan untuk menyerap air yang besar karena gugus hidroksilnya lebih banyak. Peningkatan level filler mengakibatkan daya ikat air produk yang semakin besar. Hal ini dikarenakan proporsi tepung mocaf yang ditambahkan semakin banyak sehingga daya ikat air produk yang dihasilkan juga semakin meningkat. Kandungan pati tepung mocaf berkisar antara 85 sampai 87\% (Ariyani, 2010).

Tabel 2. Rerata nilai $\mathrm{pH}$, daya ikat air dan keempukan nugget ampela dengan imbangan filler tepung mocaf yang berbeda (the average $\mathrm{pH}$, water holding capacity and tenderness score of gizzard nugget with mocaf flour in different ratio)

\begin{tabular}{lccccc}
\hline \hline \multirow{2}{*}{ Variabel (variable) } & \multicolumn{4}{c}{ Level imbangan filler : ampela (level of filler : gizzard) } \\
\cline { 2 - 6 } & $0: 100$ & $5: 95$ & $10: 90$ & $15: 85$ & $20: 80$ \\
\hline Nilai pH (pH score) $)^{\mathrm{ns}}$ & $6,56 \pm 0,08$ & $6,59 \pm 0,08$ & $6,59 \pm 0,02$ & $6,65 \pm 0,05$ & $6,62 \pm 0,01$ \\
DIA (\%) (water-holding capacity (\%)) & $34,03 \pm 4,10^{\mathrm{a}}$ & $47,79 \pm 2,73^{\mathrm{b}}$ & $56,17 \pm 4,15^{\mathrm{c}}$ & $66,58 \pm 0,85^{\mathrm{d}}$ & $69,46 \pm 0,43^{\mathrm{d}}$ \\
Keempukan (mm) (tenderness (mm)) & $14,39 \pm 2,46^{\mathrm{c}}$ & $13,92 \pm 0,33^{\mathrm{c}}$ & $12,81 \pm 0,58^{\mathrm{b}, \mathrm{c}}$ & $11,04 \pm 0,92^{\mathrm{b}}$ & $7,03 \pm 1,33^{\mathrm{a}}$ \\
\hline
\end{tabular}

${ }^{a, b, c, d}$ Superskrip yang berbeda pada baris yang sama menunjukkan perbedaan yang nyata $(\mathrm{P}<0,05)($ different superscripts at the same row indicate significant differences $(P<0.05))$.

ns non significant. 
Keempukan. Hasil pengujian keempukan pada nugget ampela berdasar level filler tepung mocaf memberikan perbedaan yang sangat nyata $(\mathrm{P}<0,01)$. Nilai keempukan tersebut menunjukkan penurunan seiring dengan peningkatan level imbangan tepung mocaf yang digunakan sehingga menghasilkan produk yang keras (Tabel 2). Peningkatan level filler tepung mocaf yang ditambahkan akan menyebabkan kandungan pati dalam produk nugget ampela akan semakin tinggi. Kandungan pati yang semakin tinggi menyebabkan gel yang terbentuk pada saat pemanasan juga semakin banyak dan akan menimbulkan kekerasan produk. Kandungan pati dalam tepung mocaf berkisar antara 85 sampai 87\% (Ariyani, 2010). Tepung mocaf memiliki kandungan amilosa sebesar $11,1 \%$ dan amilopektin sebesar 88,9\% (Fitriadenti, 2011). Perbandingan antara amilopektin dan amilosa di dalam pati akan mempengaruhi daya kembang dari makanan yang dihasilkan. Kadar amilopektin yang tinggi pada pati akan mengalami gelatinisasi mengisi rongga-rongga di antara benang-benang protein, terbentuknya ikatan-ikatan di antara molekul-molekul pati dan antara molekul protein diduga memperkokoh tekstur produk.

\section{Kualitas sensoris nugget ampela}

Hasil pengujian kualitas sensoris nugget ampela dengan menggunakan imbangan filler tepung mocaf yang berbeda disajikan pada Tabel 3 .

Warna. Hasil analisis statistik menunjukkan bahwa nugget ampela dengan peningkatan level filler tepung mocaf memberikan hasil yang tidak berbeda nyata terhadap warna nugget ampela yang dihasilkan. Hasil penelitian pada Tabel 3 menunjukkan bahwa semakin tinggi peningkatan level filler yang ditambahkan dalam pembuatan nugget ampela akan menghasilkan warna yang lebih coklat. Hasil tersebut menunjukkan bahwa tingkat penilaian panelis terhadap warna pada taraf coklat muda hingga coklat keemasan. Warna coklat yang dihasilkan disebabkan adanya reaksi pencoklatan karbohidrat antara tepung mocaf dengan protein ampela. Tepung mocaf mengandung gula pereduksi (gugus karbonil) yang dalam proses pemanasan akan terjadi kontak langsung dengan protein dan akan mempercepat reaksi pencoklatan (maillard) (Winarno, 1991). Lebih lanjut Winarno (1991) menjelaskan bahwa reaksi maillard yaitu grup karbonil dari gula reduksi bereaksi dengan grup amino dari protein daging dan asam-asam amino secara nonenzimatik.

Rasa. Hasil analisis statistik menunjukkan bahwa dengan level filler tepung mocaf yang berbeda tidak memberikan perbedaan yang nyata terhadap penilaian rasa nugget ampela (Tabel 3). Tingkat kesukaan panelis terhadap rasa dari nugget ampela dengan perbedaan level filler tepung mocaf terletak antara agak enak hingga enak. Rasa nugget ampela yang dihasilkan terutama berasal dari bumbu-bumbu yang ditambahkan selama proses pembuatan adonan. Bumbu-bumbu tersebut terdiri atas garam, bawang putih, lada dan pala serta timbulnya flavor ampela selama pemasakan. Filler tepung mocaf yang ditambahkan dalam penelitian ini hingga level $20 \%$ dapat dikatakan tidak melampaui batas sehingga tidak mengurangi cita rasa. Hal ini senada dengan pendapat Kartika et al. (1988) bahwa penambahan filler yang melampaui batas dapat menyebabkan berkurangnya cita rasa.

Tekstur. Hasil uji Kruskal-Wallis menunjukkan bahwa nugget ampela dengan peningkatan level imbangan filler tepung mocaf memberikan hasil yang berbeda nyata terhadap tekstur nugget ampela yang dihasilkan $(\mathrm{P}<0,05)$. Peningkatan level filler tepung mocaf dari 0 sampai $20 \%$ terbukti secara nyata meningkatkan tekstur nugget ampela (Tabel 3). Nugget ampela dengan formulasi tanpa penambahan tepung mocaf menghasilkan nugget yang kurang kompak dengan tekstur kasar karena tidak terdapat bahan pengisi (filler) yang dapat mengikat air (Judge et al., 1989). Nugget ampela dengan formulasi penambahan tepung mocaf 5 sampai $20 \%$ dari berat ampela menghasilkan nugget yang kompak dengan tekstur yang semakin halus. Hal ini dikarenakan tepung mocaf sebagai filler mengandung amilopektin yang tinggi sehingga

Tabel 3. Rerata skor hasil uji kualitas sensoris nugget ampela dengan imbangan tepung mocaf yang berbeda (the average of sensory qualities score of gizzard nugget with mocaf flour in different ratio)

\begin{tabular}{|c|c|c|c|c|c|}
\hline \multirow{2}{*}{ Variabel (variable) } & \multicolumn{5}{|c|}{ Level imbangan filler : ampela (level of filler : gizzard) } \\
\hline & $0: 100$ & $5: 95$ & $10: 90$ & $15: 85$ & $20: 80$ \\
\hline Warna $(\text { color })^{\mathrm{ns}}$ & $3,86 \pm 1,30$ & $3,86 \pm 1,18$ & $3,73 \pm 0,79$ & $4,20 \pm 0,94$ & $3,80 \pm 1,20$ \\
\hline Rasa $(\text { flavor })^{\text {ns }}$ & $3,60 \pm 0,73$ & $3,66 \pm 0,89$ & $3,60 \pm 0,91$ & $3,53 \pm 0,99$ & $3,60 \pm 0,63$ \\
\hline Tekstur (texture) & $2,80 \pm 0,83^{\mathrm{a}}$ & $3,40 \pm 0,82^{\mathrm{a}, \mathrm{b}}$ & $3,60 \pm 0,50^{\mathrm{b}}$ & $3,40 \pm 1,05^{\mathrm{a}, \mathrm{b}}$ & $3,80 \pm 0,67^{\mathrm{b}}$ \\
\hline Daya terima $\left({\text { acceptability })^{\mathrm{ns}}}^{\mathrm{n}}\right.$ & $3,86 \pm 0,63$ & $3,60 \pm 0,91$ & $3,60 \pm 0,91$ & $3,46 \pm 0,91$ & $3,53 \pm 0,74$ \\
\hline
\end{tabular}

${ }^{\mathrm{a}, \mathrm{b}}$ Superskrip yang berbeda pada baris yang sama menunjukkan perbedaan yang nyata $(\mathrm{P}<0,05)$ ( different superscripts at the same row indicate significant differences $(P<0.05))$.

${ }^{\mathrm{ns}}$ non significant. 
kemampuan mengikat air semakin tinggi. Fitriadenti (2011) menyatakan bahwa tepung mocaf memiliki kandungan amilosa sebesar $11 \%$ dan amilopektin sebesar 88,9\%. Umumnya untuk menghasilkan produk dengan mutu baik diperlukan amilopektin sebesar 50\% atau lebih (Ariyani, 2010).

Kramlich (1971) menyatakan bahwa terdapat tiga kelompok protein didalam daging yaitu protein sarkoplasma, protein otot dan protein jaringan ikat. Protein di dalam adonan mempunyai dua fungsi utama yaitu untuk mengemulsikan lemak dan untuk mengikat air. Ampela mengandung jaringan ikat yang cukup tinggi. Kandungan jaringan ikat yang cukup tinggi menyebabkan tekstur dari nugget ampela ini berada pada kisaran kasar hingga agak halus. Triyantini et al. (1986) cit. Damayanti (2009) menyatakan bahwa daging dengan jaringan ikat cukup banyak akan dihasilkan tekstur produk olahan yang tidak kompak dan kasar. Selain itu ampela merupakan jaringan otot yang mengandung protein otot (miosin). Protein miosin bertanggung jawab terhadap tekstur dari nugget. Protein tersebut di dalam adonan mempunyai fungsi yaitu mengemulsikan lemak serta mengikat air. Kramlich (1971) menyatakan bahwa bila miosin bergabung dengan aktin akan membentuk aktomiosin dan akan menghasilkan tekstur yang baik. Protein aktomiosin mempunyai kemampuan mengemulsikan lebih besar dibanding protein jaringan ikat dan protein sarkoplasma.

Daya terima. Hasil uji Kruskal Wallis menunjukkan bahwa nugget ampela dengan peningkatan level filler tepung mocaf memberikan perbedaan yang tidak nyata terhadap daya terima nugget ampela (Tabel 3). Penambahan filler tepung mocaf sampai pada level $20 \%$ untuk rasa juga tidak mengalami perubahan sehingga dapat dikatakan pemberian filler tepung mocaf hingga level 20\% masih dapat diterima dengan baik oleh konsumen. Hal ini disebabkan karena daya terima sangat dipengaruhi oleh subjektivitas konsumen (Sandra, 2010). Penambahan filler menurut Hendronoto et al. (2009) sebaiknya tidak melebihi $10 \%$ dari total adonan karena akan berpengaruh terhadap identitas dan cita rasa suatu produk.

\section{Kadar kolesterol}

Hasil penelitian rerata kadar kolesterol nugget ampela dengan imbangan tepung mocaf pada level $0: 100,5: 95,10: 90,15: 85$ dan 20 : 80 berturut-turut adalah $39,34 \pm 32,14 ; 36,34 \pm 28,72$; $31 \pm 24,02 ; 29 \pm 24,02$ dan $27 \pm 23,30 \mathrm{mg} / 100$ g. Hasil tersebut menunjukkan bahwa nugget ampela dengan imbangan filler tepung mocaf yang berbeda tidak memberikan perbedaan yang nyata terhadap kadar kolesterol. Hasil tersebut menunjukkan bahwa semakin tinggi peningkatan level tepung mocaf maka semakin menurunkan kadar kolesterol nugget ampela tetapi penurunan ini tidak signifikan. Hal ini disebabkan semakin tinggi penambahan tepung mocaf pada adonan nugget akan mempengaruhi imbangan antara filler dan daging (ampela) sehingga kadar kolesterol nugget ampela semakin menurun. Stephanie (2008) menyatakan bahwa kadar kolesterol pada ampela ayam mencapai 205 $\mathrm{mg} / 100$ g. Kadar kolesterol pada ampela lebih tinggi dibandingkan dengan kadar kolesterol nugget ampela. Hal ini disebabkan oleh proses pemasakan yang menyebabkan adanya komponen yang terlarut di dalam cairan yang keluar seperti lemak dan protein.

Berdasarkan hasil penelitian, level filler paling tepat sebagai adonan nugget yaitu pada level 15 dan 20\% di mana imbangan daging : filler yang membuat kadar kolesterol rendah yaitu 29 dan 27 $\mathrm{mg} / 100$ g. Kadar kolesterol nugget ampela pada penelitian lebih rendah dari kadar kolesterol daging sapi dan daging ayam sehingga tidak perlu terlalu waspada dalam mengkonsumsi nugget ampela. Harimurti (1992) menyatakan bahwa daging sapi mengandung kolesterol sebesar $500 \mathrm{mg} / 100 \mathrm{~g}$ dan kandungan kolesterol daging ayam sebesar 100 $\mathrm{mg} / 100 \mathrm{~g}$. Konsumsi kolesterol dalam batas normal masih diperbolehkan. Mengingat semakin tinggi kolesterol yang dikonsumsi akan meningkatkan timbulnya berbagai macam penyakit degeneratif yang disebabkan terjadinya arterosklerosis (Poedjiadi, 1994).

\section{Kesimpulan}

Peningkatan imbangan filler tepung mocaf ke dalam nugget ampela sampai level 20\% dapat menurunkan keempukan dan meningkatkan daya ikat air tetapi tidak mengubah nilai $\mathrm{pH}$ dari nugget ampela. Nugget ampela dengan imbangan filler tepung mocaf sampai level $20 \%$ mengalami peningkatan tekstur tetapi tidak mengalami perubahan warna, rasa dan daya terima. Peningkatan imbangan filler tepung mocaf sampai $20 \%$ ke dalam nugget ampela menurunkan penggunaan ampela sehingga menurunkan kadar kolesterol nugget ampela.

\section{Daftar Pustaka}

Ariyani, N. 2010. Formulasi tepung campuran siap pakai berbahan dasar tapioka-mocal dengan penambahan maltodekstrin serta aplikasinya sebagai tepung pelapis keripik bayam. Skripsi Sarjana Pertanian, Fakultas Pertanian. Universitas Jenderal Soedirman, Purwokerto. 
Astuti, R. 2005. Kualitas fisik dan organoleptik nugget kelinci dengan proporsi filler tepung terigu berbeda. Skripsi Sarjana Peternakan. Fakultas Peternakan Universitas Gadjah Mada, Yogyakarta.

Bouton, P.E., V.P. Harris, and W.R. Shorhthose. 1971. Effect of ultimate $\mathrm{pH}$ upon the waterholding capacity and tenderness of mutton. J. Food Sci. 36: 435-441.

Damayanti, I. 2009. Pengaruh suplementasi wortel (Daucus carota) terhadap karakteristik fisik, organoleptik dan kandungan $\beta$-karoten bakso daging sapi. Skripsi Sarjana Peternakan, Fakultas Peternakan. Universitas Gadjah Mada, Yogyakarta.

Fitriadenti, M.J. 2011. Kualitas fisik dan sensoris chicken nugget dengan substitusi filler tepung mocaf (Modified cassava flour). Skripsi Sarjana Peternakan, Fakultas Peternakan. Universitas Gadjah Mada, Yogyakarta.

Harimurti, S. 1992. Manajemen Karkas II. Pusat Antar Universitas Pangan dan Gizi Universitas Gadjah Mada, Yogyakarta.

Hendronoto, A., S. Lilis, dan M.I. Anshory. 2009. Pengaruh penggunaan berbagai tingkat persentase pati ganyong (Canna edulis Ker) terhadap sifat fisik dan akseptabilitas nugget ayam. Seminar Nasional Pengembangan Sistem Produksi dan Pemanfaatan Sumberdaya Lokal untuk Kemandirian Pangan Asal Hewan. Fakultas Peternakan Universitas Padjadjaran, Jawa Barat. ISBN: 978-60295808-0-8.

Judge, M.D., E.D. Aberle, J.C. Forrest, H.B. Hedrick, and R.A. Merkel. 1989. Principles of Meat Science. $2^{\text {nd }}$ ed. Kendall Hunt Publising Company, Derbuque, Lowa.

Kartika, B., P. Hastuti, dan W. Supartomo. 1988. Pedoman Uji Inderawi Bahan Pangan. Pusat Antar Universitas Pangan dan Gizi Universitas Gadjah Mada, Yogyakarta.
Kramlich, W.E. 1971. Sausage product. In : The Science of Meat and Meat Products. $2^{\text {nd }}$ ed. J.F. Price and B.S. Schweigert. (Eds.). W.H. Freeman and Co, San Fransisco.

Plummer, D.T. 1987. An Introduction to Practical Bio-chemistry. $3^{\text {rd }}$ ed. Mc Graw Hill Book Company, London.

Poedjiadi, A. 1994. Dasar-dasar Biokimia. Penerbit Universitas Indonesia Press, Jakarta.

Saleh, S. 1996. Statistik Non Parametrik. BPFE, Yogyakarta.

Sandra, W.A. 2010. Aplikasi edible coating berbahan dasar derivat selulosa terhadap kualitas keripik kentang dari tiga varietas. Skripsi Sarjana Pertanian. Fakultas Pertanian. Universitas Jenderal Soedirman, Purwokerto.

Soeparno. 1998. Ilmu dan Teknologi Daging, Cetakan III, Gadjah Mada University Press, Yogyakarta.

Sriwahyuni, E., T. Puspita, dan H.A.P. Putranti. 2007. Pengaruh pemberian teh hijau terhadap kadar kolesterol LDL dan HDL pada tikus putih (Ratus norvegicus strain wistar). Majalah Kesehatan FKUB 3 (1).

Steel, R.G.D. dan J.H. Torrie. 1993. Prinsip dan Prosedur Statistik. Suatu Pendekatan Biometrik. Syah, M. (Penterjemah). PT Gramedia Pustaka Utama, Jakarta.

Stephanie. 2008. Ayam ekspres fakta nutrisi rempela ayam goreng. Available at: calorielab.com/restaurants/chicken-express/ fried-chicken-gizzard. Accesion date: 22 Maret 2011.

Suhardjo. 1995. Mewaspadai pergeseran pola komsumsi pangan penduduk perkotaan. Media Konsumsi dan Informasi Pangan No 21 Volume V, Jakarta.

Winarno, F.G. 1991. Kimia Pangan dan Gizi. Penerbit Gramedia Pustaka Utama, Jakarta. 